Creative commons User License: CC BY-NC-ND

Abstracted by: EBSCOhost, Electronic Journals Service (EJS),

Google Scholar, Directory of Open Access Journals (DOAJ),

Journal Seek, Scientific Commons,

Food and Agricultural Organization (FAO), CABI and Scopus
Journal of Agricultural Extension

Vol. XX (X) XXXXXX, 20XX

ISSN(e): 24086851; ISSN(Print); 1119944X

http://journal.aesonnigeria.org

http://www.ajol.info/index.php/jae

Email: editorinchief@aesonnigeria.org

\title{
Students' Perception of West African Agricultural Productivity Programme Adopted Schools Programme in Oyo State, Nigeria http://dx.doi.org/10.4314/jae.v20i2.12
}

\author{
Samuel, J. E. \\ Department of Agricultural Extension and Management \\ Federal College of Agriculture, Moor, Ibadan, Oyo State, Nigeria \\ Email: jaybes79@yahoo.com \\ Phone: 08035839885
}

Fawole, O. P.

Department of Agricultural Extension and Rural Development

University of Ibadan, Oyo State, Nigeria.

Email: opfawole@yahoo.com

Phone: 08023355904

Badiru, O. I.

Department of Agricultural Extension and Rural Development

University of Ibadan, Oyo State, Nigeria.

Email: bodebadru@yahoo.com

Phone: 08034660732

\section{Abstract}

This study examined students' perception of the effectiveness of adopted school programme in Oyo State. Primary data were collected using structured questionnaires from 90 respondents using multi-stage procedure. Data were subjected to both descriptive and inferential statistics at $p=0.05$. The results show that $72.2 \%$ of the respondents were between 15-16 years, $51.1 \%$ were in SS2 and mostly females (58.1\%). Also, 48.9\% owned farm at home and $61.1 \%$ had farming background. The students were exposed to maize (77.8\%), cassava (77.8\%), poultry (66.7\%), fishery $(44.4 \%)$ and rabbitry (44.4\%) production. Major constraints were lack of interest $\bar{x}=2.00)$, inadequate equipment in agricultural laboratory $(\bar{x}=1.93)$ and lack of home garden $(\bar{x}=1.82)$. More than half $(55.6 \%)$ of them were favourably disposed to the programme while respondents' farming background ( $r=3.740, p \leq 0.05$ ) was significantly related to their perception of the programme. It was recommended that West African Agricultural Productivity Programme officials should focus more attention on educating students in areas that are more technologically inclined such as in animal breeding, vaccination and crop processing instead of only in areas involving manual labour such as in planting, weeding and sanitation of pen.

Keywords: West African Agricultural Productivity Programme, Adopted schools project, student farmers. 
Creative commons User License: CC BY-NC-ND

Abstracted by: EBSCOhost, Electronic Journals Service (EJS),

Google Scholar, Directory of Open Access Journals (DOAJ),

Journal Seek, Scientific Commons,

Food and Agricultural Organization (FAO), CABI and Scopus
Journal of Agricultural Extension

Vol. XX (X) XXXXXX, 20XX

ISSN(e): 24086851; ISSN(Print); 1119944X

http://journal.aesonnigeria.org

http://www.ajol.info/index.php/iae

Email: editorinchief@aesonnigeria.org

\section{Introduction}

The agricultural sector in the 1960s provided the main source of employment, income and foreign earnings for Nigerian economy. This was due to focused regional policies based on comparative advantage (Azih, 2011). Regrettably, the discovery of crude oil in the 1960s made the government to shift its priority from agriculture to crude oil and relied on food importation as a means of feeding her citizens. The glory of agriculture thus declined over the years.

Worried about her sole dependence on crude oil for its foreign exchange and food importation, the federal government of Nigeria through different regimes has made several efforts at policies and programmes for the development of her agricultural sector (Obiora and Emordi, 2013). Such programmes include the National Accelerated Food Production Programme (NAFPP), Operation Feed the Nation (OFN), Agricultural Development Programme (ADP), just to mention but a few. But these programmes have yielded little or no impact as few or no attention was paid to the youths. Youths are one of the greatest assets that any nation can have (Federal Republic of Nigeria, 1999). Laogun (2002) observes that one of the best investments in the youth is through their education.

Agricultural education is the process of training learners in the process of agricultural productivity as well as the techniques for teaching of agriculture (Egbule, 2004). Agricultural science was introduced into the secondary school curriculum in the 1960's (Makinde, 1967). The impact of this policy has drastically dwindled as the numbers of students offering agricultural science in secondary school are always on the decline Most students see it as a career for the poor (Modebelu and Nwakpadolu, 2013). Mama (1994) expressed the fact that there is danger that Nigeria might face near extinction of the farming population resulting from incapacitation of her farmers by age or death.

Despites the challenges of agricultural education in Nigeria, it remains a vital tool for the transfer of innovation. This view is also held by the Economic Community of West Africa States as it seeks to enhance agricultural productivity in the region through agricultural technology generation and dissemination. This led to the creation of West African Agricultural Productivity Programme (WAAPP) in 2007. WAAPP - Nigeria started in 2010 and collaborates with the Agricultural Research Council of Nigeria (ARCN), and operates through the National Agricultural Research Institutes (NARIs), Federal Colleges of Agriculture (FCA) and the Universities to address the challenges of slow agricultural technology generation and adoption. The NARIs were given the mandate by ARCN to re-implement Agricultural Research Outreach Centers (AROC) by adopting at least two (2) secondary schools each 
Creative commons User License: CC BY-NC-ND

Abstracted by: EBSCOhost, Electronic Journals Service (EJS),

Google Scholar, Directory of Open Access Journals (DOAJ),

Journal Seek, Scientific Commons,

Food and Agricultural Organization (FAO), CABI and Scopus
Journal of Agricultural Extension

Vol. XX (X) XXXXXX, 20XX

ISSN(e): 24086851; ISSN(Print); 1119944X

http://journal.aesonnigeria.org

http://www.ajol.info/index.php/jae

Email: editorinchief@aesonnigeria.org

within $20 \mathrm{~km}$ distance from their locations to ensure the dissemination and adoption of the generated improved technologies in those schools (WAAPP, 2013).

In Oyo States, six agricultural institutes are collaborating with WAAPP on this programme. The National Institute of Horticulture (NIHORT), Federal College of Agriculture (FCA) and Federal College of Animal Health and Technology (FCAHT) are among these institutes. These institutes have established agricultural ventures such as poultry, rabbitry, fishery, maize and cassava farms in their various adopted schools and this programme has lasted for at least two years. This study therefore seeks to measure students' perception of the effectiveness of this programme among the selected adopted Secondary Schools in Oyo State.

\section{Objectives of the study}

The general objective is to measure the students' perception of the effectiveness of WAAPP adopted schools in Oyo State. The specific objectives were to:

- identify the personal characteristics of the respondents;

- examine the agricultural enterprises the students were exposed to by the adopted school programme; and

- ascertain the constraints faced by the respondents in participating in the adopted school programme;

\section{Methodology}

The study was carried out in Oyo State which is located in the South West geopolitical zone of Nigeria between latitude $7^{0} 021$ and $9^{0} 101$ North and longitude $2^{0} 041$ and $4^{0} 30$ east. It covers an area of approximately 32,241 . 8sq. $\mathrm{km}$. The state has a population of $5,591,589$. There are $2,809,840$ males and 2,781,749 females (National Population Census, 2006).

A simple random sampling procedure was employed to select respondents for this study. Three 3 (60\%) institutes among the 5 institutes engaged in WAAPP adopted school programme were selected, the institutes are FCAH, NIHORT and FCA. Then a simple random sampling was also used to select $(50 \%)$ of the Senior Secondary Schools adopted among each of these selected institutions, with FCAH\&T adopting four (4), NIHORT two (2) and FCA with two (2) schools respectively. Therefore, four (4) schools were selected while senior secondary (SS1\&2) were purposely selected since they were the ones actively involved. The schools are Community Grammar School Oluyole, Our Lady of Apostles Secondary School, Baptist Grammar School and St. Michael African Church Grammar School with the population of 98, 100, 150 
Creative commons User License: CC BY-NC-ND

Abstracted by: EBSCOhost, Electronic Journals Service (EJS),

Google Scholar, Directory of Open Access Journals (DOAJ),

Journal Seek, Scientific Commons,

Food and Agricultural Organization (FAO), CABI and Scopus
Journal of Agricultural Extension

Vol. XX (X) XXXXXX, 20XX

ISSN(e): 24086851; ISSN(Print); 1119944X

http://journal.aesonnigeria.org

http://www.ajol.info/index.php/jae

Email: editorinchief@aesonnigeria.org

and 100 respectively and lastly, a random sample of $20 \%$ of the population of the senior secondary school students of each of the selected adopted schools was selected making a sum total of 90 respondents as the total sample size for this study. A structured questionnaire was used to collect primary data. Variables measured include students' personal characteristics, agricultural enterprises the students were exposed to, constraints faced and their perception of the adopted school programme. Students were asked to indicate the enterprises they were exposed to from the list of enterprises as carried out by the WAAPP adopted school programme. Their constraints were

ascertained and measured on a three-point rating scale. The students' perception was ascertained through a 30 - item perception statement measured on a five-point Likert type scale of strongly agree, agree, undecided, disagree and strongly disagree. All positive statements were scored as 5, 4, 3, 2 and 1 respectively while the negative statements were scored in the reverse order. Respondents were then categorized based on the group mean score. Those above the mean score have a favourable perception and those below has unfavourable perception. Data were analysed using percentage distribution, frequency count, mean and standard deviation, Chi square and Pearson Product Moment Correlation (PPMC) at $p=0.05$.

\section{Results and Discussion}

\section{Personal characteristics of respondents}

Table 1 shows that the mean age of the students was 15.0 years with majority $(72.2 \%)$ in the age range of 15 to 16 years, $51.1 \%$ were in SS2, $58.1 \%$ were females, $78.9 \%$ were Christians, $48.9 \%$ owned a farm/garden at home and a sizeable number of $61.1 \%$ had farming background. Less than half $(44.4 \%)$ and $(43.3 \%)$ of the students' fathers and mothers had secondary school education while their fathers and mothers' occupation were majorly trading (43.3\%) and trading $(76.7 \%)$, respectively. This result implies that majority of these students are quite in the age range where their minds are very inquisitive and ready to retain new knowledge such as imbibing the practical knowledge of agricultural innovation that is being disseminated by the WAAPP adopted school programme. With a sizeable number of them in senior secondary school 2 (SS2), it is envisaged that this set of students can contribute meaningfully to the focus of this study. This is in congruence with the Nigerian National Policy on Agriculture of the 80's which stated that students in senior secondary school should practice vocational agriculture. Majority of the students had farms at home where they could adopt agricultural innovations disseminated in schools. This corroborates the findings of Oladokun (2014) where 
Creative commons User License: CC BY-NC-ND

Abstracted by: EBSCOhost, Electronic Journals Service (EJS), Google Scholar, Directory of Open Access Journals (DOAJ), Journal Seek, Scientific Commons,

Food and Agricultural Organization (FAO), CABI and Scopus
Journal of Agricultural Extension

Vol. XX (X) XXXXXX, 20XX

ISSN(e): 24086851; ISSN(Print); 1119944X

http://journal.aesonnigeria.org

http://www.ajol.info/index.php/jae

Email: editorinchief@aesonnigeria.org

majority of the respondents (59.0\%) exposed to school farms affirmed that they had gardens at home. Majority having farming background also implies that there may be a positive parental influence on their perception of the programme. 
Creative commons User License: CC BY-NC-ND

Abstracted by: EBSCOhost, Electronic Journals Service (EJS), Google Scholar, Directory of Open Access Journals (DOAJ), Journal Seek, Scientific Commons,

Food and Agricultural Organization (FAO), CABI and Scopus
Journal of Agricultural Extension

Vol. XX (X) XXXXXX, 20XX

ISSN(e): 24086851; ISSN(Print); 1119944X

http://journal.aesonnigeria.org

http://www.ajol.info/index.php/jae

Email: editorinchief@aesonnigeria.org

Table 1: Distribution of respondents by personal characteristics

\begin{tabular}{|c|c|c|}
\hline Variables & $\begin{array}{l}\text { Percentage } \\
(n=90)\end{array}$ & Mean \\
\hline \multicolumn{3}{|l|}{ Age } \\
\hline Less than 14 & 17.8 & 15.30 \\
\hline $15-16$ & 72.2 & \\
\hline $17-18$ & 10.0 & \\
\hline \multicolumn{3}{|l|}{ Class } \\
\hline SS1 & 48.9 & \\
\hline SS2 & 51.1 & \\
\hline \multicolumn{3}{|l|}{ Sex } \\
\hline Male & 41.1 & \\
\hline Female & 58.1 & \\
\hline \multicolumn{3}{|l|}{ Religion } \\
\hline Christianity & 78.9 & \\
\hline Islam & 21.1 & \\
\hline Ownership of farm/garden & 48.9 & \\
\hline \multicolumn{3}{|l|}{ Farming background } \\
\hline Yes & 61.1 & \\
\hline No & 38.9 & \\
\hline \multicolumn{3}{|c|}{ Fathers educational qualification } \\
\hline No formal education & 2.2 & \\
\hline Primary education & 8.9 & \\
\hline Secondary education & 44.4 & \\
\hline NCE/Diploma & 12.2 & \\
\hline Bachelor/HND & 13.3 & \\
\hline PG Degree & 18.9 & \\
\hline \multicolumn{3}{|c|}{ Mothers' educational qualification } \\
\hline No formal education & 4.4 & \\
\hline Primary education & 7.8 & \\
\hline Secondary education & 43.3 & \\
\hline NCE/Diploma & 20.0 & \\
\hline Bachelor/HND & 8.9 & \\
\hline PG Degree & 15.6 & \\
\hline \multicolumn{3}{|l|}{ Fathers' Occupation } \\
\hline Unemployed & 2.2 & \\
\hline Trading & 43.3 & \\
\hline Artisans & 8.9 & \\
\hline Civil servants & 15.6 & \\
\hline Self employed & 30 & \\
\hline \multicolumn{3}{|l|}{ Mothers' occupation } \\
\hline Unemployed & 2.2 & \\
\hline Trading & 76.7 & \\
\hline Artisans & 2.2 & \\
\hline Civil servants & 10.0 & \\
\hline Self employed & 8.9 & \\
\hline Total & 100 & \\
\hline
\end{tabular}

Source: Field survey, 2015 
Creative commons User License: CC BY-NC-ND

Abstracted by: EBSCOhost, Electronic Journals Service (EJS), Google Scholar, Directory of Open Access Journals (DOAJ), Journal Seek, Scientific Commons

Food and Agricultural Organization (FAO), CABI and Scopus
Journal of Agricultural Extension

Vol. XX (X) XXXXXX, 20XX

ISSN(e): 24086851; ISSN(Print); 1119944X

http://journal.aesonnigeria.org

http://www.ajol.info/index.php/jae

Email: editorinchief@aesonnigeria.org

\section{Agricultural trainings/enterprises to which the students were exposed}

Table 2 indicates that while the majority $(77.8 \%$ and $77.8 \%)$ were exposed to maize and cassava, respectively $66.7 \%, 55.6 \%$ and $55.6 \%$ were exposed to poultry, fishery and rabbitry training, respectively. This implies that perhaps this programme places more emphases on crop production than on animal husbandry. This is in agreement with the findings of Ogunbiyi (1983) which reported that agricultural education in Nigeria tends to focus on agronomy at the expense of animal husbandry. This could be due to the fact that animal husbandry is capital intensive while its crop production counterpart requires mainly small amount of money to establish for students practical in school and the same time it's easier for students to start on a small scale after graduation from school.

\section{Table 2: Distribution of agricultural trainings given by WAAPP}

\begin{tabular}{ll}
\hline Variable & Percentage $^{\star}$ \\
\hline Maize & 77.8 \\
Cassava & 77.8 \\
Poultry & 66.7 \\
Fishery & 44.4 \\
Rabbitry & 44.4
\end{tabular}

*Multiple responses Source: Field survey, 2015;

\section{Constraints faced in the adopted school programme}

Table 3 highlights the constraints perceived by students in the WAAPP adopted school programme. The major constraint was lack of interest from students $(\bar{x}=2.00)$. This was followed by inadequacy of equipment in the agricultural laboratory $(\bar{x}=1.93)$, lack of home garden $(\bar{x}=1.82)$ and lack of support from parents/guardians $(\bar{x}=1.81)$, while the lowest constraint was stealing from the school farms especially during the holidays $(\bar{x}=1.44)$.

The findings on lack of interest from students could be due to the perceived tedious nature of agricultural production. This is contrary to the expectation of West African Examination Council (2006), which states that the specific objective of senior secondary school agricultural curriculum is to stimulate and sustain the students' interest in agriculture. Furthermore, their lack of interest may have been due to inadequacy of equipment in agricultural laboratory which hampers their practical exposures in agriculture. Similarly, Ani (1997) states that school farms are expected to have adequate laboratory equipment and farm implements as they are the 
Creative commons User License: CC BY-NC-ND

Abstracted by: EBSCOhost, Electronic Journals Service (EJS),

Google Scholar, Directory of Open Access Journals (DOAJ),

Journal Seek, Scientific Commons,

Food and Agricultural Organization (FAO), CABI and Scopus
Journal of Agricultural Extension

Vol. XX (X) XXXXXX, 20XX

ISSN(e): 24086851; ISSN(Print); 1119944X

http://journal.aesonnigeria.org

http://www.ajol.info/index.php/jae

Email: editorinchief@aesonnigeria.org

fundamentals of an operational school farm on which students could transfer classroom instruction to practical experiences in the field.

Table 3: Distribution of respondents according to constraints faced in the adopted school programme

\begin{tabular}{|c|c|c|}
\hline Constraints & $\begin{array}{l}\text { Mean } \\
\text { score }\end{array}$ & SD \\
\hline $\begin{array}{l}\text { Inadequacy of fund to carry out some of the programme } \\
\text { activities }\end{array}$ & 1.69 & 0.630 \\
\hline Stealing from the school farms especially during the holidays & 1.44 & 0.736 \\
\hline $\begin{array}{l}\text { Lack of continuity with an established farm during long } \\
\text { vacation }\end{array}$ & 1.68 & 0.684 \\
\hline Inadequate water supply & 1.52 & 0.691 \\
\hline Lack of home garden & 1.82 & 0.829 \\
\hline Inadequate feeds for the animals & 1.72 & 0.794 \\
\hline Poor housing for the animals as rain usually disturbs them & 1.57 & 0.720 \\
\hline Lack of student's motivation by the school authority & 1.64 & 0.708 \\
\hline Inadequacy of equipment in the agricultural laboratory & 1.93 & 0.818 \\
\hline No/insufficient agricultural teachers in my school & 1.57 & 0.735 \\
\hline Lack of support from parents/guardians & 1.81 & 0.777 \\
\hline Lack of interest from students & 2.00 & 0.779 \\
\hline
\end{tabular}

Source: Field survey, 2015

\section{Students' Perception of WAAPP Adopted School Programme}

Table 4 shows students' perception of the WAAPP adopted school programme. Students were positive on some issues related to the programme. Most students were affirmative that the school programme would have more impact if the school authority will be more committed to it $(\bar{x}=4.37)$. Furthermore, a sizeable proportion of the students $(\bar{x}=4.31)$ agreed that the programme had increased their performance in agriculture as a subject as well as that the practical on the school farms gave them a better understanding of what is being taught in class $(\bar{x}=4.7)$, and also that experiences gained in this programme would provide an avenue for selfemployment even after graduation $(\bar{x}=4.13)$. 
Creative commons User License: CC BY-NC-ND

Abstracted by: EBSCOhost, Electronic Journals Service (EJS),

Google Scholar, Directory of Open Access Journals (DOAJ),

Journal Seek, Scientific Commons,

Food and Agricultural Organization (FAO), CABI and Scopus

\author{
Journal of Agricultural Extension \\ Vol. XX (X) XXXXXX, 20XX \\ ISSN(e): 24086851; ISSN(Print); 1119944X \\ http://journal.aesonnigeria.org \\ http://www.ajol.info/index.php/jae \\ Email: editorinchief@aesonnigeria.org
}

However, it is worthy of note that despite the remarkable affirmation of majority of the respondents on the perception of this programme, a small proportion of the respondents $(\bar{x}=2.79)$ still feels that they would feel inferior as students of agriculture in the midst of friends studying other courses and likewise $(\bar{x}=2.77)$ still felt that the school farm practical were very boring. This depicts that investment in motivating students remains very paramount to all stakeholders by devising appropriate approaches such as

operating vibrant young farmers' club for carrying out farm projects. This will no doubt boost production, sustainable food security and agricultural development cum national development. Usman and Sulaiman (2006) asserted that there was a general negative belief among many people that vocational agricultural education is meant for those who do not have the brain power for vigorous academic demands of the traditional secondary school system.

The perception categorization of these students as shown in Table 4.2 also revealed that the minimum perception score is 40 and the maximum is 150 . A sizeable number $(55.6 \%)$ of the respondents were favorably disposed to the adopted school programme. This corroborates Oladokun's (2014) finding in a similar study which reports that students have positive perception towards adopted school programme though they need to be improved upon through the use of right approaches to teaching agriculture and using the school farm. 
Creative commons User License: CC BY-NC-ND

Abstracted by: EBSCOhost, Electronic Journals Service (EJS), Google Scholar, Directory of Open Access Journals (DOAJ), Journal Seek, Scientific Commons,

Food and Agricultural Organization (FAO), CABI and Scopus
Journal of Agricultural Extension

Vol. XX (X) XXXXXX, 20XX

ISSN(e): 24086851; ISSN(Print); 1119944X

http://journal.aesonnigeria.org

http://www.ajol.info/index.php/jae

Email: editorinchief@aesonnigeria.org

\section{Table 4: Distribution of respondents according to their perception of the adopted school programme}

\begin{tabular}{|c|c|c|}
\hline Statement $(n=90)$ & Mean score & SD \\
\hline This programme has increased my performance in agriculture as a subject & 4.31 & 0.956 \\
\hline I need not study agriculture as a discipline to be able to practice it & 2.74 & 1.379 \\
\hline It has provided an avenue to develop and instill interest in agriculture in students & 3.99 & 1.096 \\
\hline The programme is only a waste of time as its meant to while away the students time & 2.06 & 1.248 \\
\hline The programme is an avenue to increase my agribusiness potential & 3.99 & 1.137 \\
\hline $\begin{array}{l}\text { I dislike agricultural practical because it is laborious and it makes farmers to get old } \\
\text { within a short period of time }\end{array}$ & 2.37 & 1.137 \\
\hline This programme has encouraged me to own a farm at home & 3.46 & 1.210 \\
\hline The school farm practical are very boring & 2.77 & 1.558 \\
\hline $\begin{array}{l}\text { The practical on school farms gives me a better understanding of what is being taught in } \\
\text { class }\end{array}$ & 4.17 & 1.164 \\
\hline I will feel inferior as a student of agriculture in the midst of friends studying other courses & 2.79 & 1.525 \\
\hline This programme empowers schools with modern agricultural technologies and facilities & 4.03 & 1.222 \\
\hline I can never take up a career in agriculture because farming is meant for the rural poor & 2.22 & 1.347 \\
\hline $\begin{array}{l}\text { Agricultural science should be made compulsory to all students so that they can see the } \\
\text { benefits of practicing agriculture }\end{array}$ & 4.11 & 1.116 \\
\hline $\begin{array}{l}\text { Theft from intrusion by outsiders due to inadequate security is a discouragement for } \\
\text { establishing and managing this programme }\end{array}$ & 3.20 & 1.432 \\
\hline The establishment of young farmers club by this programme nurtures like minds together & 3.96 & 1.170 \\
\hline There is nothing educative about the agricultural excursion, it is just for fun & 2.13 & 1.447 \\
\hline $\begin{array}{l}\text { Its establishment of agricultural laboratory have exposed me to agricultural technologies } \\
\text { through video documentaries }\end{array}$ & 2.40 & 1.397 \\
\hline Agriculture is regarded as an underpaid discipline & 2.83 & 1.432 \\
\hline $\begin{array}{l}\text { This programme has made me to gain life skills such as leadership, communication and } \\
\text { teamwork }\end{array}$ & 4.11 & 1.054 \\
\hline Studying agriculture as a subject has not added any value to me & 2.07 & 1.380 \\
\hline $\begin{array}{l}\text { The experiences gained in this programme will provide an avenue for self-employment } \\
\text { even after graduation }\end{array}$ & 4.13 & 1.163 \\
\hline $\begin{array}{l}\text { I believe graduates of agriculture do not earn as much as their colleagues in other } \\
\text { profession }\end{array}$ & 2.46 & 1.375 \\
\hline I believe there is high return on investment in agriculture as it is a lucrative venture & 3.87 & 1.238 \\
\hline I will prefer to study other courses to studying agriculture & 2.64 & 1.327 \\
\hline $\begin{array}{l}\text { The programme has encouraged me to enrol for agricultural science in my WAEC } \\
\text { examination }\end{array}$ & 3.81 & 1.208 \\
\hline I feel all agricultural related jobs are dirty jobs & 2.19 & 1.413 \\
\hline $\begin{array}{l}\text { The programme has increased my adoption of improved technologies in my home } \\
\text { farm/garden }\end{array}$ & 3.82 & 1.250 \\
\hline I feel studying agriculture as a course is for students that are not intelligent & 2.36 & 1.524 \\
\hline $\begin{array}{l}\text { I believe this programme will have impact if the school authority will be more committed } \\
\text { to it }\end{array}$ & 4.37 & 1.033 \\
\hline I feel being a farmer is similar to being poor & 2.29 & 1.463 \\
\hline Perception level & Range & Percent \\
\hline Unfavourable & $67-111.36$ & 44.4 \\
\hline Favourable & $111.37-150$ & 55.6 \\
\hline \multicolumn{3}{|l|}{ Total } \\
\hline Mean & 111.37 & \\
\hline Min & 40 & \\
\hline Max & 150 & \\
\hline
\end{tabular}

Source: Field survey, 2015 
Creative commons User License: CC BY-NC-ND

Abstracted by: EBSCOhost, Electronic Journals Service (EJS),

Google Scholar, Directory of Open Access Journals (DOAJ),

Journal Seek, Scientific Commons

Food and Agricultural Organization (FAO), CABI and Scopus
Journal of Agricultural Extension

Vol. XX (X) XXXXXX, 20XX

ISSN(e): 24086851; ISSN(Print); 1119944X

http://journal.aesonnigeria.org

http://www.ajol.info/index.php/jae

Email: editorinchief@aesonnigeria.org

\section{Relationship between Respondents' Personal Characteristics and Perception of the WAAPP Adopted School Programme.}

The result in Table 5 reveals that there was only a significant relationship between respondents' farming background $\left(x^{2}=3.740, p>0.05\right)$ and their perception of adopted school programme. This indicates that students will have more favourable perception of the adopted school programme since it is an extension and an innovation of what is being practiced at home.

Table 5: Relationships between respondents' personal characteristic and their perception of the adopted school programme

\begin{tabular}{|c|c|c|c|}
\hline Variables & $x^{2}$ & $\begin{array}{l}\mathrm{R} \text { - } \\
\text { value }\end{array}$ & Df \\
\hline Age & & -0.172 & \\
\hline Sex & 0.388 & & 1 \\
\hline Religion & 0.083 & & 1 \\
\hline $\begin{array}{l}\text { Presence of farm at } \\
\text { home }\end{array}$ & 0.436 & & 1 \\
\hline Farming background & $3.740^{*}$ & & 1 \\
\hline Fathers' education & 4.791 & & 5 \\
\hline Mothers' education & 1.568 & & 5 \\
\hline Fathers' occupation & 4.871 & & 5 \\
\hline Mothers' occupation & 5.588 & & 5 \\
\hline
\end{tabular}

$\mathrm{P} \leq 0.05$ Source: Field survey, 2015

\section{Conclusion and Recommendations}

Many of the respondents had favourable perception of the programme, though they were mainly constrained by lack of interest in the programme, inadequacy of equipment in the agricultural laboratory as well as lack of home garden. The students were also mainly exposed to the crop production than the animal husbandry counterpart.

There is an urgent need for the WAAPP officials to focus more attention on educating these students in the areas that are more technologically inclined such as 
Creative commons User License: CC BY-NC-ND

Abstracted by: EBSCOhost, Electronic Journals Service (EJS),

Google Scholar, Directory of Open Access Journals (DOAJ),

Journal Seek, Scientific Commons,

Food and Agricultural Organization (FAO), CABI and Scopus
Journal of Agricultural Extension

Vol. XX (X) XXXXXX, 20XX

ISSN(e): 24086851; ISSN(Print); 1119944X

http://journal.aesonnigeria.org

http://www.ajol.info/index.php/jae

Email: editorinchief@aesonnigeria.org

in animal breeding, vaccination and crop processing instead of only in areas involving manual labour such as in planting, weeding and sanitation of pen, this will serve as a pointer to these students about entrepreneurship in agriculture. The WAAPP officials, government, curriculum developers and the school authority should apply the right approaches or methodologies towards agricultural practical through operation of active and sustainable Young Farmers Clubs to enhance motivation. Adequate equipment should be made available in their agricultural laboratory. The students should be better exposed to the animal production despite that its capital intensive.

\section{References}

Ani, C. I. (1997). Procurement, Management and Maintenance of the School Plant Dynamics of Educational Administration and Management: The Nigeria Perspective. Onitsha, Nigeria: $\quad$ Meks Publishers Limited, p. $286-296$.

Azih, I. (2011). A background analysis of the Nigerian agricultural sector (1998 to 2007) Retrieved May 8, 2015 7:25pm from http//www.manufacturing nigeria.com/index.pbp/analysis.

Egbule, P. E. (2004). Fundamentals and practice of agricultural education (enlarged education). Owerri: Totan Publishers Ltd.

Federal Republic of Nigeria. (1999). Constitution of the Federal Republic of Nigeria. Abuja (1999).

Laogun, E. A. (2002). Rural Youth Training Needs for Rural Community Development: $\quad$ Nigerian Journal of Rural Sociology, 3(2): p. 57-63.

Mama, R. 0. (1994). Instructional planning, execution and Evaluation: Competency problems of Secondary School Agricultural Science Teachers with NCE (Agriculture) Qualification. Abraka Journal of Curriculum Studies. 2(2): p.8392.

Makinde, M. A. (1967). Agriculture on the School Curriculum: TeachersMonthly.Vol XIII. P 6-7

Modebelu, M.N \& Nwakpadolu, G.M. (2013). Effective Teaching and learning of Agricultural science for food security and national sustainability. Journal of Educational and social Research. Vol. 3(4), July 2013: Doi: 10.5901/jesr.2013.2013.v3n4p161. 
Creative commons User License: CC BY-NC-ND

Abstracted by: EBSCOhost, Electronic Journals Service (EJS),

Google Scholar, Directory of Open Access Journals (DOAJ),

Journal Seek, Scientific Commons,

Food and Agricultural Organization (FAO), CABI and Scopus
Journal of Agricultural Extension

Vol. XX (X) XXXXXX, 20XX

ISSN(e): 24086851; ISSN(Print); 1119944X

http://journal.aesonnigeria.org

http://www.ajol.info/index.php/jae

Email: editorinchief@aesonnigeria.org

NPC (National Population Census) (2006). Nigeria 2006 Census Figures (Population). Retrieved May 2015, 3:00am from $\mathrm{http} /$ /www.nigeriamasterweb.com/Nigeria06Census Figs.html

Obiora, C. J and Emordi, A. I (2013), Restructuring the Agricultural Extension Service for effective Agricultural Transformation Agenda in Nigeria. Greener Journal of Agricultural Science, vol.3 (6); p. 511-517.

Ogunbiyi .O. (1983) Agricultural Science in Gesinde, S. A. and Adebara, D. (eds.) Practical teaching in higher education P. 117-135.

Oladokun, I. O. (2014).Perception of agricultural science teachers and students on the use of school farm in teaching agricultural science in secondary schools in Osun State. Unpublished. Department of Agricultural extension and Rural Development: University of Ibadan. P. 21- 58.

Usman, M. and Suleiman, A. D. (2006) "The role of Vocational Agricultural Education in the $21^{\text {st }}$ century". A paper presented at the first National conference of School of Vocational and Technical Education at the FCT College of Education, Zuba Abuja on April 4-6, 2006.

West African Agricultural Productivity Programme- Nigeria. (WAAPP) (2013). The concept and Modalities for Implementation of the Adopted Villages and Agricultural Research Outreach Centres (AROCs) by the National Agricultural Research Institutes (NARIs), Federal Colleges of Agriculture (FCAs) and Universities in Nigeria.

West African Examination Council (WAEC). (2006). West African Senior School Certificate Examination Syllabus, Nigeria, p. $13-29$ 